UDC 343.985.7

LBC 67.523

\title{
FEATURES OF THE TACTICS OF CRIME SCENE INVESTIGATION IN CASES OF ENVIRONMENTAL POLLUTION
}

\author{
Svyatoslav Yu. Biryukov \\ Volgograd Academy of the Ministry of Internal Affairs of Russia, Volgograd, Russian Federation
}

\author{
Vladimir M. Shinkaruk \\ Volgograd State University, Volgograd, Russian Federation
}

Introduction: Article 42 of the Constitution of the Russian Federation stipulates everyman's right to a favorable environment. However, currently, the environmental rights belong to the category of the most frequently violated ones. According to the Federal State Statistics Service the number of cases of pollution emissions, discharge of sewage waters and production and consumption waste in this country has a tendency to decrease, which, unfortunately, is insignificant.

In the total amount of environmental crime, the proportion of compounds of environmental pollution is low, as before: across the Russian Federation it is $0.49 \%$ as a whole. And the incidence of contamination and spoilage of land in the pipeline breaching, unauthorized landfills, air pollution, water pollution by oil products and other dangerous substances is not reduced.

The crime scene investigation for the pollution of the environment is a fundamental inquiry, the completeness and quality of which directly affects the prospects for the successful resolution of the criminal case in court.

In this regard, the authors set the goal to uncover the tactical features of conducting such important investigative actions for the detection of most of the environmental crimes as the crime scene investigation. Methods: the methodological framework of the study is a set of scientific methods, among which the main are the methods of information processing and logical analysis, synthesis, induction, deduction and generalization. Results: presented in the study the author's research of the tactical features of conducting the crime scene investigation for environmental pollution based on the judicial and investigative practice allows using them in the practical activities of authorized officials of the law enforcement agencies when recording and investigating the above facts. Conclusions: the study identified the tactical features of conducting the crime scene investigation for environmental pollution for the purposes of informing law students, and teaching staff of law schools, as well as practitioners to better understand the characteristics of investigating environmental crimes.

Key words: ecology, crime scene investigation, contamination, source of contamination, waste, nature.

УДК 343.985 .7

ББК 67.523

\section{ОСОБЕННОСТИ ТАКТИКИ ОСМОТРА МЕСТА ПРОИСШЕСТВИЯ ПО ФАКТАМ ЗАГРЯЗНЕНИЯ ОКРУЖАЮЩЕЙ СРЕДЫ}

\author{
Святослав Юрьевич Бирюков \\ Волгоградская академия МВД России, г. Волгоград, Российская Федерация \\ Владимир Маркович Шинкарук \\ Волгоградский государственный университет, г. Волгоград, Российская Федерация
}

Введение: статья 42 Конституции Российской Федерации закрепляет право каждого на благоприятную окружающую среду. Однако в настоящее время экологические права относятся к категории одних из наиболее часто нарушаемых. По данным Федеральной службы государственной статистики, количество фактов по 
выбросам загрязняющих веществ, сбросам сточных вод, образованию отходов производства и потребления в нашей стране имеет тенденцию к снижению, которая, к сожалению, незначительна.

В общей массе экологических преступлений доля составов загрязнения окружающей среды, как и прежде, низкая: по Российской Федерации в целом - 0,49 \%. При этом количество случаев загрязнения и порчи земли при прорывах нефтепроводов, несанкционированных свалках, загрязнении атмосферы, загрязнении вод нефтепродуктами и другими опасными веществами не снижается.

Осмотр места происшествия по фактам загрязнения окружающей среды является основополагающим следственным действием, от полноты и качества которого напрямую зависят перспективы успешного разрешения уголовного дела в суде.

В связи с этим авторами поставлена цель раскрыть тактические особенности производства такого важного для расследования большинства экологических преступлений следственного действия, как осмотр места происшествия. Методы: методологическую основу данного исследования составляет совокупность методов научного познания, среди которых основное место занимают методы обработки информации и логического анализа, синтеза, индукции, дедукции и обобщения. Результаты: представленное в работе авторское содержание тактических особенностей производства осмотра места происшествия по фактам загрязнения окружающей среды, опирающееся на судебно-следственную практику, дает возможность использовать их в практической деятельности уполномоченных должностных лиц правоохранительных органов при документировании и расследовании вышеназванных фактов. Выводы: в результате исследования определены тактические особенности производства осмотра места происшествия по фактам загрязнения окружающей среды, информирования обучающихся по направлению подготовки «Юриспруденция», педагогических работников юридических вузов, а также практических работников в целях более полного понимания особенностей расследования преступлений, связанных с загрязнением окружающей среды.

Ключевые слова: экология, осмотр места происшествия, загрязнение, источник загрязнения, отходы, объекты живой природы.

\section{Введение}

Статья 42 Конституции Российской Федерации закрепляет право каждого на благоприятную окружающую среду. В настоящее время экологические права относятся к категории одних из наиболее часто нарушаемых. По данным Федеральной службы государственной статистики, количество фактов по выбросам загрязняющих веществ, сбросам сточных вод, образованию отходов производства и потребления в нашей стране имеет тенденцию к снижению, которая, к сожалению, незначительна [1].

В общей массе экологических преступлений доля составов загрязнения окружающей среды, как и прежде, низкая: по Российской Федерации в целом - 0,49 \% [2]. При этом количество случаев загрязнения и порчи земли при прорывах нефтепроводов, несанкционированных свалках, загрязнении атмосферы, загрязнении вод нефтепродуктами и другими опасными веществами не снижается.

Осмотр места происшествия по фактам загрязнения окружающей среды является основополагающим следственным действием, от полноты и качества которого напрямую зависят перспективы успешного разрешения уголовного дела в суде.

Осмотром называется следственное действие, заключающееся в непосредственном восприятии, фиксации объектов осмотра, обнаружении, изъятии следов преступления и других вещественных доказательств в целях установления обстоятельств расследуемого события.

Осмотр места происшествия - это в большинстве случаев неотложное следственное действие, состоящее в обнаружении, восприятии, изучении и фиксации состояния, свойств и признаков предметов материального мира, находящихся на месте происшествия, в целях выяснения характера произошедшего события, личности преступника, мотивов преступления и иных обстоятельств, подлежащих установлению в ходе расследования противоправного деяния [1, с. 72].

\section{Общие положения тактики осмотра места происшествия}

Применительно к расследованию преступлений, связанных с загрязнением окружающей среды, указанное следственное дей- 
ствие проводится незамедлительно [5, с. 160]. В основном это связано с относительно быстрой изменчивостью обстановки места происшествия, которая обусловлена как погодными условиями, так и особенностями производственной деятельности предприятий [7, с. 41]. Кроме того, роль фактора оперативности производства осмотра возрастает, если источник загрязнения расположен на значительном расстоянии от места обнаружения вредных последствий, а также в контексте принятия необходимых мер по скорейшему устранению выявленных загрязнений с целью снижения причиняемого вреда окружающей среде и здоровью людей.

При подготовке к осмотру необходимо подыскать и пригласить нужных специалистов. Оказываемое ими содействие в собирании доказательственной информации повышает результативность данного следственного действия $[2$, с. 4$]$. Так, при правильном изъятии образцов загрязняющих веществ с места происшествия не исключается возможность с помощью экспертизы обнаружить в них признаки различных примесей, специфических для определенного хозяйствующего субъекта. Кроме того, к участию в производстве следственного действия целесообразно привлечь представителей предприятия - источника загрязнения, в случае если он установлен.

Следует заранее подготовить требуемые технические средства: фото-, видеозаписывающую, измерительную аппаратуру, приборы для отбора проб воздуха, воды, почвы, дозиметры (пробоотборники и дозиметры могут быть получены в органе экологического контроля, на предприятии или в НИИ соответствующего профиля). В ряде случаев сотрудников правоохранительных органов необходимо обеспечить средствами индивидуальной защиты, специальной одеждой и обувью.

Деятельность уполномоченных лиц правоохранительных органов на месте происшествия начинается с оценки условий осмотра: определение степени зараженности местности, воздуха; безопасности нахождения на месте людей; принятие необходимых мер индивидуальной защиты и обеспечения безопасности участников следственного действия.

Следующим направлением действия должностных лиц правоохранительных орга- нов является пресечение дальнейшего выброса вредных веществ при условии, что известен источник загрязнения.

Осмотр места происшествия в криминалистике принято делить на общий (статический) и детальный (динамический) [6, с. 172]. Как правило, в ходе общего осмотра с учетом определения его границ, узловых элементов обстановки места происшествия избирают методы осмотра.

Под узловыми элементами обстановки места происшествия понимаются участки территории (акватории), подвергшиеся загрязнению, где можно обнаружить его вредоносные последствия [4, с. 38]. Ими могут быть источники загрязнения, например, очистное сооружение, пруд-отстойник, место свалки с непосредственно прилегающей к нему местностью. Узловые элементы места происшествия подвергаются тщательному осмотру. В случае, если источник загрязнения установлен, представляется целесообразным начать осмотр с объекта - источника загрязнения, используя эксцентрический способ осмотра; в противном случае осмотр следует начать с загрязненного участка, применяя концентрический способ осмотра. Кроме того, в отдельных случаях с учетом обстановки места происшествия логично проводить осмотр фронтальным способом в направлении, обратном пути распространения вредных веществ, или комбинируя несколько упомянутых способов осмотра.

В целях обнаружения источника загрязнения необходимо учесть данные о характере рельефа местности, направлении и силе ветра, скорости течения воды и т. п.

На стадии детального (динамического) осмотра проводится съемка места происшествия: обзорная, узловая и детальная. На этой стадии необходимо уделить внимание не только источнику, но и последствиям загрязнения: местам скоплений отходов, наибольшего сосредоточения погибших животных или пораженных растений.

Обязательным для этого вида осмотра места происшествия является отбор проб в той или иной среде для последующего экспертного исследования в целях установления источника загрязнения, а также характера и степени поражения загрязнением объектов окружающей среды. 


\section{Тактические особенности осмотра места происшествия}

Осмотры мест происшествий, производимые по рассматриваемой категории уголовных дел, можно дифференцировать по объектам осмотра:

- участки окружающей среды, подвергшиеся загрязнению и порче: водоемы и прилегающая территория, земельные участки и т. п.;

- погибшие объекты живой природы: рыбы, животные, насекомые и др.;

- инженерные сооружения по утилизации, обеззараживанию и очистке вредных сбросов или выбросов, а также отходов: отстойники, пруды-накопители, ловушки загрязняющих веществ;

- производственные территории;

- места постоянного или временного хранения отходов;

- транспортные средства, используемые для вывоза отходов, вредных веществ.

В ходе рабочего этапа осмотра места происшествия необходимо зафиксировать следующие узловые элементы:

1. Вид осматриваемого объекта, его особенности, могущие иметь значение для дела (наименование и другие общие данные: участок суши, реки, канала, подвергшихся загрязнению, свалка и т. д.; примыкающие к зоне загрязнения лесные угодья, сельскохозяйственные насаждения и т. д. В случае, если загрязненный участок находится на территории со специальным режимом охраны, отмечается вид этой территории (национальный парк, заповедник, заказник, водоохранная зона и т. п.).

2. Координаты и размер загрязненного участка; его удаленность от источника загрязнения, жилых зданий, мест водозабора; наличие, цвет, запах, особенности и глубина проникновения загрязняющих веществ; площадь и интенсивность загрязнения; воздействие загрязняющих веществ на окружающую среду, в чем выразилось это воздействие.

3. Степень загрязненности объекта: прозрачность, например, воды или воздуха (легкое помутнение, полупрозрачна, непрозрачна в тонком слое); температура (например, повышение температуры воды в водоеме выше определенного уровня может повлечь гибель или ухудшить условия жизнедеятельности вод- ных организмов); метеорологические условия в момент осмотра (температура воздуха, осадки, направление и скорость ветра).

Фиксируя в протоколе факт наличия загрязняющих веществ, необходимо указать:

- их местонахождение (например, на поверхности почвы, воды, в придонном слое или на дне водоема);

- их цвет, запах со степенью его выраженности, размерные характеристики (например, желеобразная масса на воде с сильным специфичным запахом, высотой до 4 мм на площади $100 \times 120$ м);

- структуру и консистенцию (в частности, мелкодисперсная масса, волокнистое вещество или клейкая маслянистая жидкость).

4. Признаки изменения естественной окраски растительности: темные пятна по краям листьев (результат воздействия хлороводорода), темно-серый налет сажи, белая окраска растений (результат воздействия натриевых солей или хлора).

5. Аномальное поведение рыб, животных (отсутствие реакций на внешние раздражители, судороги, замедление дыхательного ритма и др.).

В случае, если погибла рыба, фиксируются ее вид, размеры, поза (наличие или отсутствие изогнутости тела), цвет и яркость наружных покровов (тусклые, яркие), повреждения на теле (язвы и пр., их количество, локализация, форма, размеры, цвет), наличие наслоений, слизи, газовых пузырьков, потеря чешуи, травмы; состояние различных частей: рта, жабр, глаз, плавников (целостность плавниковой каймы), чешуйчатого покрова (целостность, ерошение), запах, издаваемый рыбой. Количество погибших рыб (в абсолютном или относительном выражении). Например, на каждом из трех случайно взятых участков реки возле берега на площади 1 кв. м обнаружено по 12 погибших рыб, а на каждом из трех случайно взятых участков в центре реки обнаружено по 7 погибших рыб; вес погибшей рыбы составил от 70 г до 1,5 кг).

В случае, если обнаружены трупы животных, предположительно погибших вследствие загрязнения их среды обитания, фиксируются их вид, месторасположение трупов относительно источника загрязнения; позы трупов, состояние рта, глаз; наличие, количе- 
ство, консистенция, цвет рвотных масс, испражнений. Кроме того, необходимо достаточно подробно описать признаки загрязнений, имеющихся на трупах и вокруг них, с указанием их локализации, характера и запаха.

\section{Выводы}

В заключение хотелось бы отметить, что знание тактических рекомендаций и специфики производства рассматриваемого следственного действия будет способствовать не только успешному расследованию преступлений указанной категории, привлечению виновных к уголовной ответственности, но и обеспечению конституционного права на благоприятную окружающую среду.

\section{СПИСОК ЛИТЕРАТУРЫ}

1. Бирюков, С. Ю. Методика расследования организации незаконной миграции / С. Ю. Бирюков, Е. В. Кушпель. - Волгоград : ВА МВД России, 2010. $-144 \mathrm{c}$.

2. Бирюков, С. Ю. Особенности расследования организации незаконной миграции : автореф. дис. ... канд. юрид. наук / Бирюков Святослав Юрьевич. - Волгоград, 2008. - 215 с.

3. Министерство внутренних дел Российской Федерации : офиц. сайт. - Электрон. текстовые дан. Режим доступа: http://мвд.рф. - Загл. с экрана.

4. Скориков, Д. Г. Особенности расследования преступлений экстремистской направленности / Д. Г. Скориков, С. Ю. Бирюков, В. М. Шинкарук. - Волгоград : ВА МВД России, 2013. - 64 с.

5. Соловьева, Н. А. Взаимосвязь процессуальной истины и разумных сроков ее установления / Н. А. Соловьева, В. М. Шинкарук // Вестник Волгоградского государственного университета. Серия 5, Юриспруденция. - 2014. - № 4. - С. 159-164.

6. Соловьева, Н. А. Методика расследования детоубийств : дис. ... канд. юрид. наук / Соловьева Наталья Алексеевна. - Волгоград, 2001.- 232 с.

7. Соловьева, Н. А. Уголовно-процессуальный риск: понятие и содержание / Н. А. Соловьева, В. М. Шинкарук // Вестник Волгоградского госу- дарственного университета. Серия 5, Юриспруденция. -2014 . - № 1. - С. 40-44.

8. Федеральная служба государственной статистики : офиц. сайт. - Электрон. текстовые дан. Режим доступа: http://www.gks.ru. - Загл. с экрана.

\section{REFERENCES}

1. Biryukov S.Yu., Kushpel E.V. Metodika rassledovaniya organizatsii nezakonnoy migratsii [Methods of Investigation of the Organization of Illegal Migration]. Volgograd, VA MVD Rossii, 2007. 144 p.

2. Biryukov S.Yu. Osobennosti rassledovaniya organizatsii nezakonnoy migratsii: avtoref. dis. ... kand. yurid. nauk [Peculiarities of Investigation of Illegal Migration Organization. Cand. jurid. sci. abs. diss.]. Volgograd, 2008. 215 p.

3. Ministerstvo vnutrennikh del Rossiyskoy Federatsii: ofits. sayt [Ministry of Interior of the Russian Federation: Official Website]. URL: http:// мвд.рф.

4. Skorikov D.G., Biryukov Yu.S., Shynkaruk V.M. Osobennosti rassledovaniya prestupleniy ekstremistskoy napravlennosti [Features of Investigation of Extremist Crimes]. Volgograd, VAMVD Rossii, 2013. $64 \mathrm{p}$.

5. Solovyeva N.A., Shinkaruk V.M. Vzaimosvyaz protsessualnoy istiny i razumnykh srokov ee ustanovleniya [The Interrelationship of the Procedural Truth and a Reasonable Time of Its Establishment]. Vestnik Volgogradskogo gosudarstvennogo universiteta. Seriya 5, Yurisprudentsiya [Science Journal of Volgograd State University. Jurisprudence], 2014, no. 4, pp. 159-164.

6. Solovyeva N.A. Metodika rassledovaniya detoubiystv: dis. ... kand. yurid. nauk [Methods of Infanticide Investigation. Cand. jurid. sci. diss.]. Volgograd, 2001.232 p.

7. Solovyeva N.A., Shinkaruk V.M. Ugolovnoprotsessualnyy risk: ponyatie i soderzhanie [Criminal Procedure Risk: Concept and Content]. Vestnik Volgogradskogo gosudarstvennogo universiteta. Seriya 5, Yurisprudentsiya [Science Journal of Volgograd State University. Jurisprudence], 2014, no. 1, pp. 40-44.

8. Federalnaya sluzhba gosudarstvennoy statistiki: ofits. sayt [Federal State Statistics Service: Official Website]. URL: www.gks.ru. 


\section{Information about the Authors}

Svyatoslav Yu. Biryukov, Candidate of Juridical Sciences, Associate Professor, Head of the Department of Preliminary Investigation of Educational and Scientific Complex on Preliminary Investigation in the Department of Internal Affairs, Volgograd Academy of the Ministry of Internal Affairs of Russia, Istoricheskaya St., 130, 400089 Volgograd, Russian Federation, Bir.slav@yandex.ru.

Vladimir M. Shinkaruk, Candidate of Juridical Sciences, Associate Professor, Department of Criminal Procedure and Criminalistics, Volgograd State University, Prosp. Universitetsky, 100, 400062 Volgograd, Russian Federation, shinkaruk_67@mail.ru, upik@volsu.ru.

\section{Информация об авторах}

Святослав Юрьевич Бирюков, кандидат юридических наук, доцент, начальник кафедры предварительного расследования учебно-научного комплекса по предварительному следствию в органах внутренних дел, Волгоградская академия МВД России, ул. Историческая, 130, 400089 г. Волгоград, Российская Федерация, Bir.slav@yandex.ru.

Владимир Маркович Шинкарук, кандидат юридических наук, доцент кафедры уголовного процесса и криминалистики, Волгоградский государственный университет, просп. Университетский, 100, 400062 г. Волгоград, Российская Федерация, shinkaruk_67@mail.ru, upik@volsu.ru. 